\title{
Partnership Income Tax on Social and Economic Development in Nigeria
}

\author{
Osho, Augustine E. Ph.D \\ Department of Accounting, Achievers University, P. M. B. 1030, Owo, Nigeria
}

Agbeleye, Ademola James

Accounts Department, State Universal Basic Education, P. M. B. 610, Akure, Ondo State

Ojeme, Ruth Blessing

Department of Accounting, Achievers University, P. M. B. 1030, Owo, Nigeria

\begin{abstract}
This research work examines the partnership income tax on social and economic development in Nigeria. The objective of the study was to examine how partnership income tax revenue contributes to social and economic development in Nigeria. Secondary data are obtained from relevant literatures such as Central Bank of Nigeria Statistical Bulletin and National Bureau of Statistics publications. Data were tested using the Ordinary Least Square Linear Regression model. Findings show that, partnership Income Tax Revenue is making a unique significant contribution to the social and economic development in Nigeria and composition of the GDP. It is concluded that the results affirmed a rise in the income tax from partnership firms leads to an increase in social and economic development in Nigeria. It is recommended that government should ensure effective utilization of the income accrued taxation to encourage continuity in tax payment by the tax payers.
\end{abstract}

Keywords: Economic Development, Gross Domestic Products, Partnership, Partnership Income Tax, Personal Income Tax, Social Development

DOI: $10.7176 /$ RJFA/10-6-03

Publication date:March $31^{\text {st }} 2019$

\subsection{Introduction}

Partnership is one of the most exciting and dynamic areas of research within business society relations. Partnership has different sectors such as public, private and public private organization. The aim of most partnerships is to solve economic, social and environmental problems through collaboration (Crane, 1998). Partnerships include both public and private firms and increasingly depend on local business for leadership. Since the inception of the major employment programs that grew out of the state and local efforts have benefitted from the federal government's leadership, technical expertise, and superior taxing powers.

Basically, the partnership income is not chargeable to tax; rather, the income of each partner would be subjected to tax individually based on the income derived from the partnership.

The importance of taxation is the public services cover by the government such as social security and welfare, including pensions and medical care, social infrastructure development, such as waterworks and roads as well as to education, policing, firefighting and national defense. Taxes are used to fund these public services. In order for us to help each other in an effort to form a better society, it is necessary that the tax burden is shared broadly and fairly among the members of society. Government have traditional used to build up hard infrastructure, they are now increasingly experimenting with using ppps for soft issues with varying constitutions and aims (Dixon, Dogan, \& Kouzmin, 2004; Milliman \& Grosskopf, 2004; Skeltcher \& Sullivan, 2002; Teegen $\&$ Doh, 2003). Partnerships are increasing being adopted by many civil society organizations in preference to a confrontational approach towards firms and governments in order to develop novel solutions to old problems, thereby aiming to increase the efficiency and effectiveness of their activities (Le Ber \& Branzei, 2009).

\subsection{Review of Related Literature}

\subsubsection{Concept of Partnership}

Partnership is a business arrangement or organization that is owned and established where two or more individuals or entities pool their resources together to run a business and agree to share the profits and losses of the business based on their partnership deed. The partnership Act of 1890, defines partnership as a relationship that exists or subsists between or among persons carrying on business in common with a view of profit. Partnership is an association of two or more persons who come together with a view of making profit. A partnership has a minimum of two and a maximum of 20 members. However, section 19 (2) (b) of the Companies and Allied Matters Act (CAMA) allows a partnership of more than twenty persons to be formed in Nigeria provided it is for the purpose of carrying on practice as legal practitioners, by persons each of whom is a legal practitioner, or as accountants by persons each of whom is entitled by legal practice as a chartered 
accountant.

According to Ojo (2009), partnership can be defined as an advanced study of the taxation of sole traders. This is because a partnership may be a combination of two or more sole traders. Consequently, the general principles applicable to the taxation of sole traders are also applicable.

Partnership is an association of two or more people that pooled their resources together to serve as coowners of a business for profit. It can also be viewed as an extension of its owners for tax purposes. In the opinion of Clarke and Fuller (2010) and NGOs Brinkerhoff and Brinkerhoff (2011), defined partnership as government innovative ways of producing public goods in collaboration with firms, Since the early 2000s the international organizations such as the United Nations and the World Bank have embraced public-private partnership as a means of providing global public goods like the environmental protection or poverty alleviation (Glasbergen, Birmann \& Mol, 2007).

\subsubsection{Concept of Income Tax}

Income tax is levied by the federal, most state and some local governments. Income taxes are generally imposed on corporations, estates, trusts and individuals. Most taxing jurisdictions use a pay as you earn system for collecting taxes. State and local income taxes, most state and a few cities impose income taxes. The calculation of these usually relies on some degree of federal income tax law and computations. Therefore, an income tax is a tax imposed on individuals or entities (taxpayers) that varies with respective income or profits (taxable income). Income tax generally is computed as the product of a tax rate time's taxable income. Taxation rates may vary by type or characteristics of the taxpayer. The tax imposed on companies is usually known as corporate tax and is levied at a flat rate. However, individuals are taxed at various rates according to the band in which they fall. Further, the partnership firms are also taxed at flat rate. Most jurisdictions exempt locally organized charitable organizations from tax. Capital gains may be taxed at different rates than other income. Credits of various sorts may be allowed that reduce tax. Some jurisdictions impose the higher of an income tax or a tax on an alternative base or measure of income.

According to Osho, Olemija and Falade (2019), Tax is the nexus between state and its citizens, and tax revues are the lifeblood of the social contract. An income tax is a tax that governments impose on income generated by businesses and individuals within their jurisdiction. By law, taxpayers must file an income tax return annually to determine their tax obligations. Income taxes are a source of revenue for governments. They are used to fund public services, pay government obligations, and provide goods for citizens.

Henry (1997) as cited by Osho, Ajibola and Omolola (2019) defined tax as monetary charge imposed by the Government on persons, entities or property, levied to yield public revenue. Cooley (1924) in his own opinion defined taxes as enforced proportional contributions from persons and property, levied by the state, by virtue of its sovereignty, for the support of government and for all public needs.

According to Okafor, (2012) as cited by Osho, Omotayo and Ayorinde (2018) are of the opinion that tax is a charge levied by the government on the income or wealth of a person or corporate organization for the common benefit of all. The term does not include specific charges made against a particular person or properties for current or permanent benefits and privileges accruing only to those paying such charges.

According to Ololade (2017), Partners not partnerships, are taxed in Nigeria. But partnership arrangements affect the computation of the tax liability of partners. Taxation of partners is governed by the Personal Income Tax Act (PITA). Under PITA, partners are taxed as individuals with chargeable incomes derived from the partnership business and other sources. They are taxed according to their profit shares from partnership income. To determine partners' tax liabilities, the partners first compute the partnership income and then distribute it to the partners according to the articles of partnership. The partners deduct allowances and reliefs. Afterward, the balance is taxed under PITA.

Although partners and not partnerships are taxed in Nigeria, taxing partners cannot be achieved without identifying the income the partnership brings to the table. Understanding the nature and terms of the partnership is key to determining the tax liability of partners.

Income of a partner is computed as if the partnership was a separate person resident in Canada. The tax year is the fiscal period of the partnership. Elections in relation to tax treatment in the computation of income with respect to a number of matters must be made at the partnership level and, therefore, be treated in the same manner by all partners. This election must be made on behalf of all members of the partnership by one who has the authority to make that election. These matters include: the role of accounts receivable; exclusion of "work in progress" from the computation of income from a professional business; the transfer of property from partner to partnership; capital gains computation; and the amount of Capital Cost Allowance to be claimed.

Each taxable capital gain and allowable capital loss from the disposition of property owned by the partnership and the amount of any income or loss of the partnership from such sources as business or property will be calculated for each fiscal period of the partnership. However, this income is not taxed at the partnership level but is allocated to the partners according to the terms of the partnership agreement. Once the partnership income is recognized and shared between the partners, income taxes can be determined on the partner's total 
income for the assessment year.

The income that flows through to each partner retains its original character, thereby enabling the partners to benefit, for example, from the dividend tax credit, the foreign tax credit and the capital gains deduction.

The tax paid by citizens is called personal income tax. Personal income tax is tax paid on one's personal income as distinct from the tax paid on the firm's earnings. In an incorporated firm, the owners (shareholders) pay taxes on both their income (salary or dividend from the firm) firm's income (profits). In partnerships and sole-ownerships, the tax is paid only once on the firm's profits.

Therefore, tax is a compulsory contribution imposed by government on her citizens in order to provide public goods and services and ensure their social and economic welfare.

\subsubsection{Concept of Social and Economic Development on Income Tax}

Tax law is increasingly being used to achieve economic goals of the government. Attempts at stimulation or temperance of the national economy and encouragement or discouragement of specific activities or industries have led to large number of recent amendments to the code. Tax system is also used for social considerations, particularly with regard to individual taxation. Tax-favored treatment concerning certain employer provided benefits, childcare costs, and charitable contributions and education costs are responses to various social goals. Tax laws discourage expenditures that are contrary to public policy.

Social development is about investing on people and improving the well-being of every individual in society so they can reach their full potential. The success of society is linked to the well-being of each and every citizen. It requires the removal of barriers so that all citizens can journey toward their dreams with confidence and dignity. It is about refusing to accept that people who live in poverty will always be poor. It is about helping people so they can move forward on their path to self-sufficiency. While, Economic development is the process by which a nation improves the economic, political, and social well-being of its people. It is a policy intervention endeavor with aims of improving the economic and social well-being of people.

According to Ogbonna and Appah, (2012) as sited by Ikebujo, Ibanichuka and Akani (2016), the economic and social development of any country depends to a large extent on the quantum of revenue generated for the provision of infrastructure in that given country. And one major means of generating the revenue for providing the needed infrastructure is through a well-structured tax-system. In the opinion of Sanni, (2007), said Tax can be used as an instrument of social engineering, to stimulate economic growth and development. Therefore, the social and economic development of a country depends on the amount of revenue generated in a given period.

Economic development is the sustained, concerted actions of policy makers and communities that promote the standard of living and economic health of a given area. Economic development can also be referred to the quantitative and qualitative changes in the economy

Economic development is the sustained, concerted actions of policy makers and communities that promote the standard of living and economic health of a given area. Economic development can also be referred to the quantitative and qualitative changes in the economy

Economic development is the sustained, concerted actions of policy makers and communities that promote the standard of living and economic health of a given area. Economic development can also be referred to the quantitative and qualitative changes in the economy

Economic development is the sustained, concerted actions of policy makers and communities that promote the standard of living and economic health of a given area. Economic development can also be referred to the quantitative and qualitative changes in the economy

According to Ogbonna and Ebimobowei (2012) "the political, economic and social development of any country depends on the amount of revenue generated for the provision of infrastructure in that given country". 


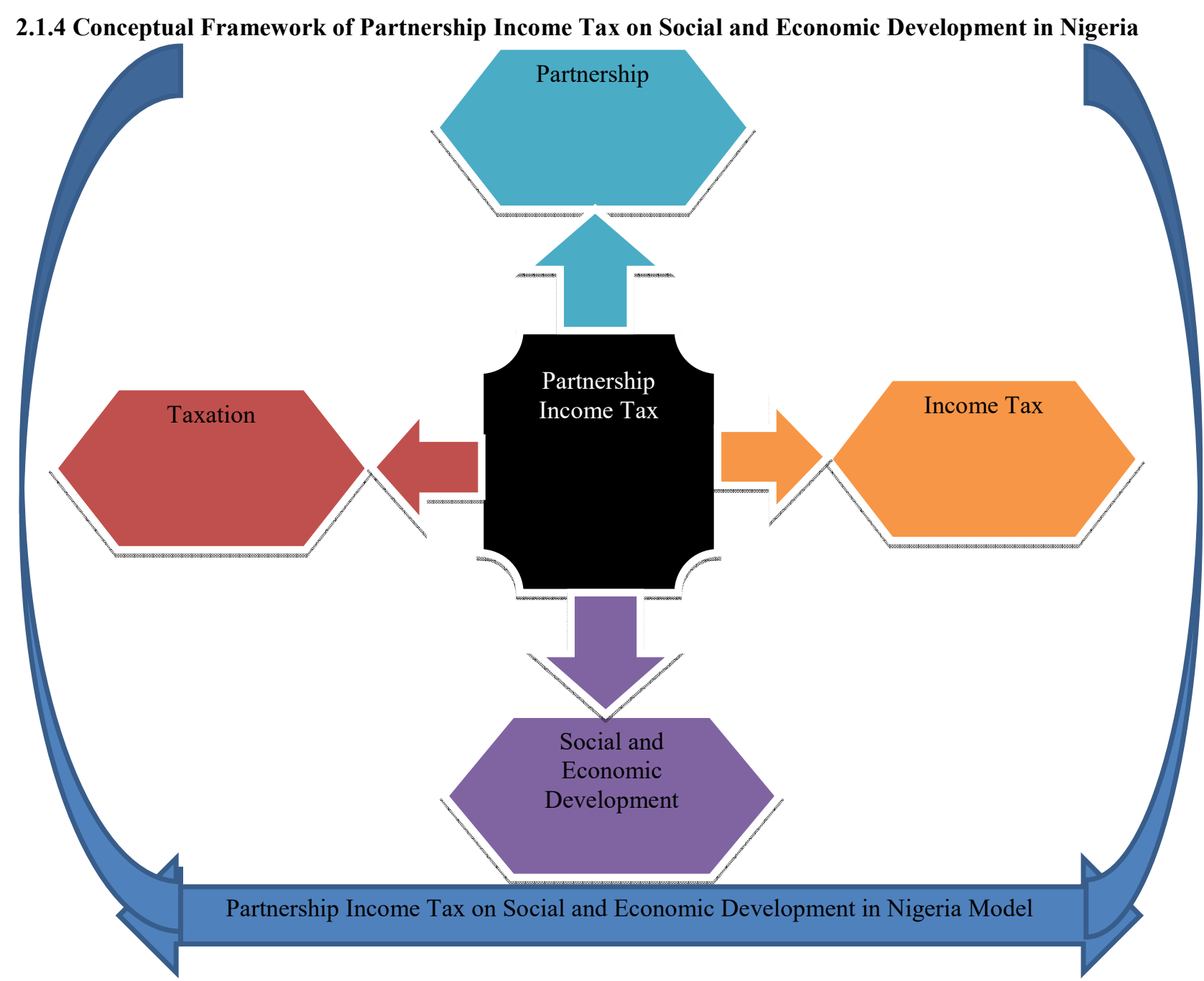

\subsection{Theoretical framework}

\subsubsection{Benefit theory}

This theory is based on the idea that taxes should be imposed in proportion to the benefit received. This approach would seem to be fair in practice but the benefit is difficult to measure. For instance, childless couples may not always feel they should contribute to the provision of state education and yet indirectly they will derive a benefit from living in an educated community.

In developing an economic of a nation like Nigeria, there will always be poor people who should be supported by the state through transfer payments paid out of taxation. The benefit theory is of a little use as the benefits received by redistribution to the poor cannot be subjected to taxation.

According to Musgrave and Mustagrave (2004), in their book "public finance in theory and practice," earmarked taxes could increase efficiency, equity and lead to better expenditure decision. Deran (1965), argue in favor of earmarked taxes put forward as applies the benefit theory of taxation. It assures the minimum level of expenditure for government functions that can reduce the cost of specific projects $b$ assuring continuity and can overcome resistance to new taxes or increased rates of tax.

\subsubsection{Socio Political Taxation Theory}

According to Ogbonna and Appah (2012) affirmed that this justifies the imposition of taxes for financing state activities and for the provision of a basis for apportioning the tax burden between members of the society. They advocated that, for tax system which is not designed to serve individuals but one that cures the ills of the society as a whole. The society is made up of individuals but more than the sum total of its individual members. The system of taxation should be directly towards the health of the society as a whole since individuals are integral part of the broader society (Chigbu, Akujuobi \& Appah, 2012).

\subsubsection{Ability to Pay Theory}

These theories uphold that, taxes imposed on tax payer should be based on the progressive tax approach which maintains that taxes should be levied according to a tax payer's ability. The system of taxation requires that 
higher income tax payer pays more than those with lower income. The in tenet of this theory is that, the burden of taxation should be share by the member of the society on the principle of equity and justice and that this principle necessitates that tax burden is apportioned according to their ability to pay. Adam Smith principle of equity advocated that, the amount of tax payable should be equal. This means that, the proportion of tax payable to earned income is justified. Equity and justice is assumed sonly when the tax system is based on the ability of the tax payer to pay the amount levied as tax liability.

\subsubsection{Expectancy Theory}

According to Ayuba (2014) and Bhartia (2009), Taxation is such that every tax proposal passes the test of practicality and must be sole consideration before the tax authorities in a bid for tax proposal. It strongly emphasizes that, the economic and social objective of the state is considered irrelevant since it is meaningless to have a tax that cannot be levied and effectively collected.

\section{Empirical Review}

According to Tulder1, Seitanidi, Crane \& Brammer, (2015), the researchers, research on enhancing the Impact loops for Channeling partnership Studies, which was an Editorial to a special symposium issue. The methodology used in this study was a method which has a link with the outcome of a partnership to the objective as defined by the participant. The paper addresses only part of the impact challenge as partners might raise noncompatible and unrealistic expectation. Also, the paper took stock of two discussions which are the discourse in cross-sector partnership research on how to assess impact and the discourse in impact assessment research on how to deal with more complex organizations and projects. The paper concluded by applying these insights to the four papers included in this special issue. The results of the finding of the four papers include:

1. Individual (inside partner): the project efficiency operational mindsets and employee engagement changed input activities. This can be control by non-employee.

2. Organization or partner: the project performance tactical legitimacy institutionalization management tools changed output and outcome. This can be control by non-partnership projects from the same organization.

3. Partnership: mission related performance synergistic value creation for two organizations standard setting changed outcome portfolio of partnership.

Society or issue: issue related performance filling institutional gaps creation of new governance structures contribution to social good changed systemic impact. Individual involved stakeholders longitudinal.

Eberts and George (2002) examined the role of partnerships in economic development and labour markets in the United States. The paper describes the role of local partnerships in the delivery of workforce and economic development services in the United States. The study uses primary date, 14 delegates from the European countries visited about two dozen partnership organizations in the U.S. Also, the study summarizes the history of local partnerships in the United States, describe the leadership roles of the federal government in fostering partnership and provide case studies of current public-private partnerships that the delegate visited on tour. The found and concluded that, the importance of active business involvement is a key component in a partnership's ability to efficiently manage federal and state employment policies. More so, state and local economic development efforts focus more and more on improving the competitiveness of their regions, economic development. Federal support of nationwide industry modernization programs and the development of regional industrial cluster initiatives seem reasonable. The effective pursuit of the workforce and the economic development efforts at the state and local levels tests the depth and strength of the community's civil assets. Also, the ability to link businesses, government and other stakeholders into effective partnership depends on areas civic entrepreneurs. Individuals must come from government, business, and the broader community and be willing to work together through partnerships to address their local issues.

In Gale and Samwick (2017), the paper examined the effects of income tax changes on economic Growth. The study examined how changes to the individual income tax affect long-term economic growth. The researchers were silent about the methodology used in the investigation. The study found that, from all the analysis tax changes will have the same impact on growth. Reforms that improve incentives reduce existing subsidies, avoid windfall gains, and avoid deficit financing will have more auspicious effects on the long-term size of the economy, but in some cases may also create trade-offs between equity and efficiency.

Ayeni, Ibrahim and Adeyemi (2017) examined tax revenue and Nigeria economic growth. The paper was designed to investigate the tax revenue and Nigeria economic growth for the three decade, used time series data from 1986-2015. The objective of the study was to investigate the significant difference between the effects of oil and non-oil tax revenue on economic growth in Nigeria. The study uses secondary data, collected from central Bank of Nigeria, statistical Bulletin and National Bureau of statistics. They found that, there was a great level of difference between the oil and non-oil tax revenue on economic growth in Nigeria. The study also reveal that, tax revenue has a positive impact on the economic growth in Nigeria specially in socio-economic as oil and non-oil taxes revenue contributed $75 \%$ and $25 \%$ share of the total revenue covered the period of the three decade from 1986-2015. And also, oil and non-oil tax revenue has contributed $7.7 \%$ and $2.5 \%$ for the same 
period to Real Gross Domestic Product (RGDP).

\subsection{Methodology}

This study adopted the exploratory and ex-post facto design. The exploratory design is used to gather relevant materials from secondary data such as text books, journal articles and so on while the ex-post facto design is adopted on the basis that it does not provide the study an opportunity to control the variables mainly because they have already occurred and cannot be manipulated. The data for this study is obtained from National Bureau of Statistics concerning; Gross Domestic Product (GDP) and Personal Income Tax (PIT) which is a proxy for measuring partnership income taxation and covering the period of years 1988-2017 (30years).

\subsection{Model Specification}

In this study, the model contained two equations. The first is on determinant of partnership income tax in Nigeria, the second is on effect of partnership income tax indicators on Social and Economic development in Nigeria using gross domestic product as the dependent variable; the explanatory variable includes: Personal Income Tax (PIT), which is a proxy for measuring partnership income tax in Nigeria.

The model used is expressed mathematically as thus:

Equation one and two written as

$\mathrm{PNIT}=\{\mathrm{PIT}\}$

$\mathrm{GDP}=\mathrm{f}\{\mathrm{PIT}\}$

Where:

PNIT $=$ Partnership Income Tax,

$\mathrm{PIT}=$ Personal Income Tax,

$\mathrm{GDP}=$ Gross Domestic Product.

Multivariate Regression model would be; $Y=\alpha+\beta_{1} X_{1}+\beta n X n+\varepsilon$

$\mathrm{Y}=$ the value of dependent variables;

$\alpha=$ the constant term;

$\beta=$ the coefficient of the function;

$\mathrm{X}=$ the value of independent variables;

$\mathrm{e}=$ error term.

Thus, Regression equation becomes;

$\mathbf{G D P}=\alpha+\beta_{1}[\mathrm{PIT}]+\varepsilon$.

\subsection{Results}

4.1 Test of hypotheses

$\mathbf{H}_{\mathbf{0}}$ : Personal Income Tax has no significant impact on Gross Domestic Product in Nigeria.

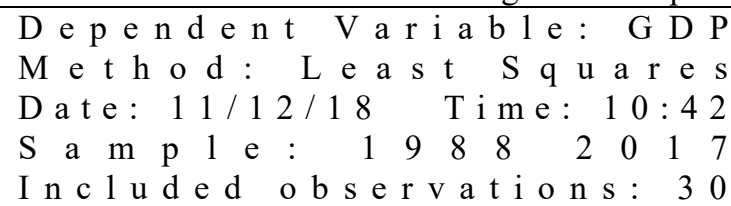

\begin{tabular}{|c|c|c|c|c|}
\hline 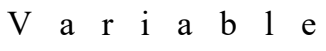 & Coefficient & Std. Error & t-Statistic & Prob. \\
\hline $\mathrm{T}$ & 3.014015 & 5.624234 & 0.535898 & 0.5966 \\
\hline $\mathrm{C}$ & 31000955 & 13238504 & 2.341726 & 0.0271 \\
\hline$R-s q u$ a $r$ e d & 0.596584 & \multirow{7}{*}{\multicolumn{2}{|c|}{$\begin{array}{l}\text { Mean dependent var } \\
\text { S.D. dependent var } \\
\text { Akaike info criterion } \\
\text { Schwarz criterion } \\
\text { Hannan-Quinn criter. } \\
\text { Durbin-Watson stat }\end{array}$}} & 35496567 \\
\hline Adjusted R-squared & -0.027116 & & & 53471620 \\
\hline S.E. of regression & 54191749 & & & 38.52270 \\
\hline Sum squared resid & $7.64 \mathrm{E}+16$ & & & 38.61786 \\
\hline Log likelihood & -537.3179 & & & 38.55180 \\
\hline$F-s t a t$ i s t i c & 0.287187 & & & 0.277116 \\
\hline Prob(F-statistic) & 0.010925 & & & \\
\hline
\end{tabular}

\section{Source: Researchers' E-Views Output.}

\subsection{Discussion of Findings}

From the analysis, the goodness of fit of the model as indicated by R-square shows a good fit of the model. RSquare value of 0.597 or 59.7 per cent indicated that the model fits the data well; the total variation in the 
observed behaviour of Gross Domestic Product is explained by variation in Partnership Income Tax up to 60 per cent. The remaining 40 per cent is accounted for the stochastic error term. To test for the overall significance of the model, the ANOVA of the F-statistics is used. To test for the individual statistical significant of the parameters, the t-statistics of the respective variables were considered. Considering their probability values which were automatically generated during the computation process by the Econometric Views (E-Views) software, the constant term is significant at 5 per cent level and GDP is significant at 5 per cent level. The a priori expectations about the signs of the parameter estimates were also considered. The study also tests for auto correlation in the residual of the model. Durbin-Watson statistic result was 0.277 which showed that the model is not free from serial correlation of residual because it is less than 2 . Therefore, the estimates should be taken with caution.

The study empirically examined the effect of partnership income tax on social and economic development of the Nigerian economy. It showed the relationship between incorporated variable; Partnership Income Tax and Gross Domestic Product. As can be seen in the tables above, the positive coefficient of Partnership Income Tax Revenue confirms priori expectation of a positive relationship with the Gross Domestic Product. In evaluating the model, the R. Squared (which is the coefficient of determination) of 0.597 means that 59.7 percent of variations in the Gross Domestic Product is explained by revenue generated from Partnership Income Tax Revenue which is impressive. With the probability (F- statistic) value of 0.0109 , partnership Income Tax Revenue is making a unique significant contribution to the investment, social and economic development of Nigeria and composition of the GDP. The results refuted that a rise in the income tax from partnership firms leads to an increased in social and economic development.

\subsection{Conclusion}

This study examined partnership income tax revenue on social and economic development in Nigeria. It was found that partnership income tax revenue plays a vital role in the economy activity and making funds available to government that can be used to adequately execute enormous projects to the benefit of the citizens of the country. Findings from this study contribute towards a better understanding of partnership income tax and show it contributions to the social growth and economic development of Nigeria. The study concluded that, the increasing amount generated from partnership firms yearly has improved social, economic well-being and a better standard of living for the Nigerian citizens.

Furthermore, the role of partnership income taxation in developing a nation's economy has been described as irreplaceable. Though, the issue of tax leakages is a global concern which Nigerian situation cannot be exempted as a result of the scale of corruption practices in Nigeria. It is therefore concluded that partnership tax revenues have significant impact on social and economic development in Nigeria for the period under review. The study then recommends that:

- $\quad$ There is need for government to clearly state the basic objectives of its tax system and the relationship between these objectives especially the administration of partnership income tax. This will give the tax administrators a sense of direction and educate the tax payers (Partnership Firms) on the reasons to file their tax returns as at when due.

- Strict penalties should be meted to partnership firms who avoid and evade tax payments in order to minimize the incidence of tax evasion and tax avoidance.

- Government should organize intensive training for all tax officials so as to identify the loopholes in tax payment system and to carry out their job effectively.

- Finally, government should ensure effective utilization of the income accrued taxation to encourage continuity in tax payment by the tax payers.

\section{Reference}

Ayeni, A. P., Ibrahim, J. \& Adeyemi, A. O. (2017). T ax revenue and Nigeria economic growth. European Journal of Accounting, Auditing and Finance Research 5 (11): 75-85.

Bhartia, H.L (2009). Public Finance (14th Edition). New Delhi: Vikas Publishing House PVT Limited

Brinkerhoff, D. W., \& Brinkerhoff, J. M. (2011). Public-private partnerships: Perspectives on purposes, publicness, and good governance. Public Administration and Development, 31(1), 2-14

Chigbu, E. E., Akujuobi, L. E., \& Appah, E. (2012). “An Empirical Study on the Causality between Economic Growth and Taxation in Nigeria. Current Research Journal of Economic Theory, 4 (2):29-38. ISSN 20534086(Print), ISSN 2053-4094(Online)

Clarke, A., \& Fuller, M. (2010). Collaborative strategic management: strategy formulation and implementation by multi-organizational cross-sector social partnerships. Journal of Business Ethics, 94(1), 85-101.

Cooley, T. M. (1924). The Law of Taxation. 4th ed., Chicago: Callaghan.

Crane, A. (1998). Exploring green alliances. Journal of Marketing Management, 14(6), 559- 579.

Deran, E. Y. (1965). "Earmarking and Expenditures: A Survey and a New Test". National Tax Journal: 354-61. 
Dixon, J., Dogan, R., \& Kouzmin, A. (2004). The dilemma of privatized public services: Philosophical frames in understanding failure and managing partnership terminations. Public Organization Review, 4, $25-46$.

Eberts, R. W. \& George A. E. (2002). "The Role of Partnerships in Economic Development and Labor Markets in the United States.” Kalamazoo, MI: W.E. Upjohn Institute. http://research.upjohn.org/up_workingpapers/75

Gale, W. G. \& Samwick, A. A. (2017). Effects of Income Tax Changes on Economic Growth. In The Economics of Tax Policy, 13-39. doi:10.1093/acprof:oso/9780190619725.003.0002.

Gale, W. G. \& Andrew, A. S. (2014). Effects of Income Tax Changes on Economic Growth. Economic Studies, no. September, pp. 1-16. doi:10.1093/acprof:oso/9780190619725.003.0002.

Glasbergen, P., Birmann, F., \& Mol, A. P. J. (2007). Partnerships, governance and sustainable development. Cheltenham: Edward Elgar.

Henry, C. B. (1997). Black's law dictionary, Abridged 6th Edition, centennial, Trade PB, 75877

Ikebujo, O. S., Ibanichuka, E. L. \& Akani, F. N. (2016). A Time Series Analysis of Effect of Tax Revenue on Economic Development of Nigeria. Developing Country Studies ISSN 2224-607X (Paper) ISSN 2225-0565 (Online) $6(9)$.

Le Ber, M. J., \& Branzei, O. (2009). (Re)forming strategic crosssector partnerships relational processes of social innovation. Business and Society, 49(1), 140-172

Milliman, J., \& Grosskopf, J. (2004). Improving the regulatory enforcement settlement process: Applying collaborative solutions for businesses and environmental agencies. Environmental Quality Management, 13, $25-43$.

Musgrave, R. A. \& Musgrave, P. B. (2004). Public Finance in Theory and Practice. Tata McGraw Hill, New Delhi, India.

Ogbonna, G. N. \& Appah, E. (2012). Tax Revenue and Nigerian Economic Growth. European journal of Accounting, Auditing and Finance Research 5 (11): 4.

Ogbonna, G. N. \& Appah, E. (2012). Impact of Tax Reforms and Economic Growth in Nigeria: A Time Series Analysis. Current Research Journal of Social Science 4(1):62-6

Ojo, S. (2009). "Fundamental principles of Nigeria tax", 2nd Edition, Lagos, Sagribra Lax Publications.

Okafor, R. G. (2012). Tax revenue generation and Nigerian economic development. European Journal of Business and Management, 4(19): 49-57.

Ololade, O. (2017). Taxation of Partners and Partnerships in Nigeria. Available at SSRN: https://ssrn.com/abstract=2965515 or http://dx.doi.org/10.2139/ssrn.2965515

Osho, A. E., Ajibola, I. O. \& Omolola, R. A. (2019). The Impact of Capital Gains Tax on Investment, Social and Economic Development in Nigeria. European Journal of Business and Management. ISSN 2222-1905 (Paper) ISSN 2222-2839 (Online) 11 (2): 30-38.

Osho, A. E., Olemija, T. L. \& Falade, A. B. (2019). The Influence of Tax Revenue on Government Capital Expenditure and Economic Growth in Nigeria. European Journal of Business and Management. ISSN 22221905 (Paper) ISSN 2222-2839 (Online) 11 (2): 39-49.

Osho, A. E., Omotayo, A. D. \& Ayorinde, F. M. (2018). Impact of Company Income Tax on Gross Domestic Products in Nigeria. Research Journal of Finance and Accounting. United Kingdom. ISSN 2222-1697 (Paper) ISSN 2222-2847 (Online) 9 (24): 105-115.

Sanni, A. U, (2007). "Tax Reform in the Capital Market". A welcomed development seminar paper; Ogun state Internal Revenue Service seminar.

Skelcher, C., \& Sullivan, H. (2002). Working across boundaries. Palgrave Macmillan: Collaboration in Public Services.

Teegen, H., \& Doh, J. P. (2003). Globalization and NGOs. Santa Barbara, CA: Praeger

Tulder1, R. V., Seitanidi, M. M., Crane, A. \& Brammer, S. (2015). Enhancing the Impact of Cross-Sector Partnerships. Four Impact Loops for Channeling Partnership Studies. Cross Mark. J Bus Ethics (2016) 135:1-17 DOI 10.1007/s10551-015-2756-4 